\title{
WHERE DID THE TRADE LIBERALIZATION DRIVE LATIN AMERICAN ECONOMY: A CROSS SECTION ANALYSIS RAJAGOPAL ${ }^{*}$
}

\begin{abstract}
The institutional reforms towards trade liberalizations in Latin America during the 1980s and the 1990s have introduced a good measure of import competition, but trade policies alone are not sufficient to create a competitive environment in an economy. Most of the region's economies have changed from restrictive to open policies, but unlike trade liberalization in Europe, most trade barriers in Latin America have been reduced unilaterally. These countries favored free trade to improve their economies in terms of savings, export share, foreign reserves and growth of GNP during the reforms period. After decades of weak growth in Latin American countries, the manufacturing sector exports have shown optimistic results in recent years following the international trade agreements. The proposed study examines the trends of export dynamism in the Latin American countries and attempts to analyze whether the current pace of growth is sustainable. This paper attempts to analyze the extent of trade competitiveness and its impact on the economic welfare measures in the Latin American countries. The analysis concentrates on measuring the economic growth of the Latin American countries during 1950-2003. Nash equilibrium has been calculated to measure the economic welfare gains among the trading blocs in the Latin American region.
\end{abstract}

\section{JEL Classifications: C21, C51, E21, E22, F15, F43}

Keywords: Trade competitiveness, institutional reforms, regional growth, trading blocs, investment, economic welfare, exports share

\section{Introduction}

The trade policy in Latin America and the Caribbean (LAC) had involved very high levels of protection and of government intervention in the pre-reforms period. The active pursuit of import substitution policies reduced the openness and efficiency of the regional economies. It also increased their external vulnerability, as they became dependent on a narrow range of export products, with little ability to absorb external shocks. This state of affairs changed markedly in the 1980s and 1990s, when most countries of the region moved to liberalize their trade regime. Trade policy reform in LAC in the 1990s has been both widespread and extensive, and the region now shows a fairly open trade regime. Such a sharp policy reversal clearly had an impact on trade flows, and those effectively underwent significant changes in the past decade (Loser and Guerguil, 1999). The Latin American countries have not had much experience with

\footnotetext{
*Rajagopal, Professor of Marketing, Business Division, Monterrey Institute of Technology and Higher Education, ITESM Mexico City Campus, Mexico DF.

E-mail: rajagopal@itesm.mx

Acknowledgement: Author acknowledges the technical support provided by Ms. Ananya Rajagopal, Graduate Student of Industrial and Systems Engineering, ITESM, Mexico City Campus in preparing this research paper.
} 
competition policies in the past. Combined with restrictive trade policies, the absence of competition policies has often led to monopolized domestic markets.

The strong trade liberalizations in Latin America during the 1980s and the 1990s have introduced a good measure of import competition, but trade policies alone are not sufficient to create a competitive environment in an economy. The presence of nontraded goods, vertical integration, monopolized distribution systems, the limited use of trade policies to foster competition, and sometimes the use of anti-dumping measures, countervailing duties, and safeguards as protective devices have constrained the effectiveness of trade policy as an instrument of competition policy. Competition policies, such as anti-trust, merger controls, and other regulatory means, can prevent the abuse of market power, dominance, exclusionary practices, and complicity among competitors. Domestic competition is further enhanced by foreign ownership and liberalized investment regimes. These latter provisions provide a market presence that enhances competition. A study discusses that trade and competition policies are essential complements and when used together they can lead to higher levels of welfare. There are of course tensions between these two policies that arise from globalization, regional policies, technical barriers, certain forms of industrial policies, and macroeconomic exigencies (Rajapatirana, 1994).

This paper attempts to analyze the extent of trade competitiveness and its impact on the economic welfare measures in the Latin American countries. The discussion reviews the studies contributed towards evaluating the free trade policies of the Latin American countries during the post-reforms period and evaluates the process of trade reforms in Latin America during the period 1950-2003. The paper also discusses some important issues related to the economic stabilization and trade reform policies. The analysis concentrates on the total factor productivity and exports in the countries of the region.

\section{Review of Literature}

Free Trade Agreement.- There have been varying arguments on the impact of trade agreements on the economy and welfare measures. It has been concluded in one of the studies that the preferential trade agreements are mostly welfare reducing since the partner countries might end up with severe welfare losses due to substantial amount of trade diversion (Bhagwati and Panagariya, 1996). Another study finds that Free Trade Areas constitute a potential threat to the world trading system because these types of agreements are, in general, trade diverting and they lead to formation of new interest groups who oppose the multilateral tariff reductions (Krueger, 1996). Interestingly, some researchers present a completely different picture about the implications of bilateral trade agreements. Nordstrom (1995) finds that regional trade agreements might provide trading blocs with stronger incentives to pursue multilateral trade liberalization since establishing these types of agreements allows small countries to deal more effectively with large trading blocs. Perroni and Whalley (1996) indicate that recent regional trade agreements generally take the form of Free Trade Associations in which member countries can choose their external tariff rates freely. 
Several emerging market economies have experienced large and persistent trade deficits, following the liberalization reforms of the late $80 \mathrm{~s}$ and early 90s. The Argentine experience has endorsed the extent to which trade imbalances in the 1990s resulted from income and relative price movements were associated with structural changes from shifts in foreign trade elasticity during the reforms period. New estimates of export and import equations are studied using a broader set of variables than previous studies and distinguishing between intra and extra MERCOSUR trade (Catao and Falcetti, 2002). The results reveal that considerable export sensitivity to world commodity prices, domestic absorption, and economic activity in Brazil, combined with a high income elasticity of imports, are key determinants of Argentina's trade balance. In particular, a study draws attention on the historical context of economic institutions in the region, and how these institutions have influenced competition policy enforcement (Leon, 2001). The study delineates three conditions necessary for competition policy enforcement in Latin American countries- (a) to achieve efficiency and innovation development goals through the promotion of a pro-market policy agenda (b) institutional incentives placed on competition agencies, and (c) the challenge of adverse anti-market social values where the policy is to be implemented. The discussion in this study is based on the mainstream efficiency-equity economic analysis, and focuses on neo-institutional development concepts of economic process.

The change in economy has taken place through the free trade policies in Latin America since 1980's, and most of the region's economies have changed from restrictive to open policies. But unlike trade liberalization in Europe, most trade barriers in Latin America have been reduced unilaterally. Recently bilateral or multilateral agreements have been considered, especially preferential trade agreements within the region. A Study evaluates the relevance and desirability of multilateral free trade agreements (such as NAFTA) for the Latin American continent and the Caribbean, with an emphasis on how they affect trade flows (Michaely, 1999). Is a preferential trade agreement among some Latin American countries determined as an economic welfare driver? The evidence strongly suggests little likelihood that these agreements will succeed in Latin America. Paradoxically, the intense liberalization in recent years has made it less likely that such agreements would be beneficial except possibly for agreements between some countries and Brazil, Mexico, or (to a lesser extent) Argentina. The trade policy can be used for protection even without high tariffs or quantitative restrictions through anti-dumping measures, countervailing duties, and safeguard measures, which would limit, rather than promote, competition. Caution should be the guiding principle in the use of these measures and they should be GATT compatible in law, and competition promoting in spirit. However, Latin American countries have recently made impressive progress in trade reforms; there has been limited use of competition policies (Rajapatirana, 1994).

The spatial characteristics of a country have significant effects on trade and are generally not correlated with other determinants of income. However, merely examining the correlation between trade and income cannot identify the cause and effect relationship between these two variables. In this context a study constructed the measures of the geographic component of countries' trade and uses those measures to obtain instrumental variables estimates of the effect of trade on income (Frankel and 
Romer, 1999). The results provide no evidence that ordinary least-squares estimates overstate the effects of trade, though they suggest that trade has a positive effect on income in developing countries.

A significant cross-section of commentators from countries in the weaker half of the Basin, particularly those that make up the Commonwealth Caribbean, have not persuaded that NAFTA and other macro-phenomena offer any hope for countries in the periphery. It is argued that the winners will be among those countries that restructure their politicaleconomic base while rigorously negotiating their terms of entry into the free trade agreement area (Marshall, 1998). Indeed, much of the outcome will be politically determined and cannot be entirely 'read off' from existing economic structures and relationships. The production sharing practice followed by the multinational companies in the LAC countries as a result of the globalization process also helped in gearing up the export competitiveness. A comparative case study approach has been conducted to explore the inter-organizational dynamics of the Mexican apparel industry's post-NAFTA export dynamism, and it assesses the upgrading prospects that this dynamism entails for exporters in Mexico. The results of fieldwork conducted in three apparelproducing clusters in north, central, and southern Mexico are discussed. The key finding from this commodity chain analysis of linkages between US clients and local producers is that NAFTA-inspired full-package networks provide opportunities for some apparelmanufacturing clusters to upgrade their operations beyond the assembly-export role traditionally associated with Mexico's maquiladora plants (Bair, 2002). Evidence of industrial upgrading includes expanded employment opportunities in activities such as textile production, the generation of linkages to local suppliers, and improved working conditions in plants producing for brand-name clients.

Business plays a critical yet poorly understood role in trade policymaking. An analytical framework that focuses on the distribution of business trade preferences, discusses the forces that cause those preferences to change, and the ability of different groups to exert political influence over policy in reference to Mexico in the 1980s and 1990 (Thacker, 2000). Large exporting firms increased their weight due to shifts in the international context, the condition of the domestic economy, and previous government policies. Policymakers granted political access to players whose economic and political leverage had risen, typically those who controlled numerous investment resources and sought out a direct role in policymaking. Many of these players also favored free trade. Business participation in trade policy reflects these patterns. Large, outward-oriented firms played an increasingly important role in Mexico's adoption of free trade policies over the 1980s and early 1990s. Analytical explanations have been developed and tested in reference to the motivations that drove the process of economic integration known as MERCOSUR (Southern Cone Common Market). The hypotheses tested are those that focus on elite considerations of geo-political, political economic and domestic political factors when deciding to participate in international economic integration (Kaltenthaler and Mora, 2002). The study found that policy elites in MERCOSUR member states have been primarily driven by domestic political considerations when they have furthered the integration process. This leads to the conclusion that MERCOSUR is not likely to develop the kinds of supranational 
governance institutions present in the European Union, as policy elites in MERCOSUR member states desire to maintain a great deal of domestic policy autonomy

Trade and Monetary Reform. -The impact of increased global economic integration on national and regional environmental standards has been studied in general by a large number of researchers. However there are not many studies available on the institutional reforms in reference to the Latin America. A study reveals the role of market mechanisms in facilitating the dissemination of environmental standards from greener nations to less green ones and the impact of international agreements on transborder environmental problems (Vogel, 1997). It argues that current regional and international governance mechanisms are adequate to enable nations which have the resources and the commitment to improve environmental quality to do so, either on their own or in cooperation with other nations with similar values and resources. The most common pattern of economic reforms in Latin America has been, first, radical liberalization, and second, implementation of prudential norms that moderated the initial liberalization. The policy changes related to the financial system (namely, the removal of interest-rate controls, elimination of mandated credit to "priority" sectors, privatization of state banks, liberalization of the foreign investment regime, and more recently, improvements in the regulatory framework) have improved both the banking system and the stock market. The traditional view about fiscal and monetary policies in developing countries (and particularly in LAC) is that they are pro-cyclical, contributing to deepen business cycles (e.g. Djistra, 2000; Mortimore, 1998). It has been argued that governments relax their policies during booms and restrict them during busts, due to weak institutions, unfavorable politicaleconomic equilibrium, and volatile access to international capital markets. The most common pattern of financial reforms in the LAC countries has been towards radical liberalization and implementation of prudential norms that moderated the initial process of liberalization. However, growth has been inadequate in the post-reforms period not because of the failure of reforms to yield the expected growth payoff on the basis of international experience, but because of the combination of an unfavorable external environment with the insufficient depth and breadth of reforms.

The study done by Glick and Moreno (1999) analyzes the role of money, credit, trade and competitiveness variables in signaling currency crises in a sample of East Asian and Latin American countries over the period 1972-1997. The Bivariate tests administered in the study suggest that money and credit, as well as trade and competitiveness variables appear to behave differently around crisis episodes from the periods of tranquility, suggesting that they may help signal currency crises. In multivariate regressions, which allow for the identification of marginal contributions of individual variables, reductions in real domestic credit and in foreign reserves as well as appreciation in the real exchange rate, imply increases in the probability of the monetary crisis and lead to the exports decline in the Latin American countries. The study revealed that real exchange rate appreciation appeared to play a greater role in predicting currency crises in East Asia, while foreign reserve losses play a greater role in Latin America due to shrinking exports and low trade competitiveness. 
Multiple exchange rates, multiple interest rates, protection of domestic products with licenses, quotas, tariffs in the excess of what would have been necessary for infant industries, and a welter of regulations and bureaucratic obstacles to normal business in general have detrimental effects on economic growth. Mainstream economic theory suggests that economic welfare would be maximized when distortions are minimized. Accordingly, a removal of distortions of both macroeconomic and microeconomic nature would have beneficial effects on economic activity and the rate of growth (Igor 2000). For the early reformers, among them Bolivia, Chile, Costa Rica, and Mexico, the expansion of international trade as a share of GDP, occurred mostly in the 1986-89 period. In the 1990s, the Argentina, Brazil, Paraguay, and Uruguay constituents of MERCOSUR experienced very high growth rates of the volume of trade. While the respective trade shares of Colombia, Mexico, and Peru increased rapidly (certainly as a result of the liberalization process), the improvement was not as large in the oilexporting economies of Ecuador and Venezuela despite a liberalization program similar to that of the former countries (especially Colombia). However, the tariff and quantitative restrictions often impede the process of trade liberalization. The higher is the average level of dispersion of tariffs and para-tariffs in terms of custom duties and taxes; more is the distortion of international trade. The measure applied to evaluate the level of tariffs and para-tariffs is the weighted average rate of tariff and para-tariff charges that is used to weigh their respective shares in regional or global imports (Pritchett, 1996). However, international exchange-rate regimes became less persistent than hard pegs and floats in LAC after the Asian crisis. The choice of exchange-rate regimes and their transitions do matter for inflation and growth (Rajagopal, 2005).

Kamin (1998) describes research comparing the response of inflation to changes in exchange rate competitiveness in various regions of the world with evidence that an empirical relationship between the rate of inflation and the level of the real exchange rate, which was documented for Mexico in previous research contributions, holds for a large set of other countries as well. He argues that such results may pose a dilemma for policy-makers, since it implies that it may not be possible to achieve low inflation and high export competitiveness simultaneously. However, the study demonstrates that the responsiveness of inflation to the real exchange rate has been much higher in Latin America and has distorted the growth of foreign trade despite institutional reforms that were introduced in early 90's by the LAC countries.

Trade Liberalization and Productivit.- After decades of weak growth in Latin American countries, the manufacturing sector exports have shown optimistic results in recent years following the international trade agreements. The previous research studies find that the competitive base for export performance in the Latin America and Caribbean (LAC) countries is very narrow and is dominated largely by nonmanufactured products like raw materials. However, the countries in the LAC region possess strength in low-end manufacturing and exporting, where it is vulnerable to competitive entry and technological change. These processes have meant increasing competition for firms in national and international markets. The LAC countries are urged to increase competitiveness in order to increase employment, production and growth under a context of globalization. The region has been highlighted as an important player in both, as an important source of competitiveness for localized firms 
and in the reallocation of economic activity. Agglomeration economies and innovations are considered the most important forces in agglomeration leading to increasing competitiveness and to improving living conditions for people living in such regions (Jorge Vera, 2001). The relationship between trade liberalization and manufacturing labor productivity growth for 27 industries in seven Latin American countries from 1970 to 1998 has been studied with the variables export and import growth and a commercial reform index (Paus et.al., 2003). The analysis of the study captures the various channels through which productivity and trade liberalization have been related. The study finds a significant positive correlation between all three variables and productivity growth.

The factors, which determine the long-run real exchange rate in Argentina, Colombia and Mexico, may be distinguished as real and nominal determinants. Co-integration analysis is utilized to establish that the real exchange rate has an equilibrium relationship with real variables (the terms of trade, capital flows, productivity, and government share of GDP) which excludes nominal variables (nominal exchange rate, money) and central bank intervention. Variance decompositions reveal that among the real variables that determine the real exchange rate, the terms of trade and productivity explain much of the variation in the real exchange rates. The impulse response functions are broadly consistent with theoretical predictions and shocks to the nominal variables have only transitory effects on the real exchange rate (Joyce and Kamas, 2003). The structural reforms have been initiated in the macro areas including economic activity, international trade, financial markets, generation and use of public resources, governance, and labor markets. Trade leads to specialization, contributes to the total factor productivity (TFP), and offers comparative advantages for the other countries. It also expands potential markets that allow the domestic companies to take advantage of economies of scale and to diffuse technology, innovation and managerial practices through close alliances with the foreign firms (Igor 2000, Rajagopal 2004).

The export competitiveness of a country is also significantly driven by the resources availability in the country and harnessing them. These resources may broadly be classified as natural, monetary, R\&D, production and market infrastructure and human resources. The relationship between export competitiveness and investment in machinery, allowing for imperfect substitution between domestically produced and imported machinery has been analyzed in reference to the developing countries by Mody and Yilmaz (2002). A translog export price function is estimated for developed, export-oriented developing, and import-substituting developing countries in a panel data setting. Between 1967 and 1990, imported machinery helped lower export prices for export-oriented developing countries. The study revealed that innovative effort based on imported technologies can be a precursor to the development of domestic innovation capabilities, which may ultimately become the main nexus of a country's innovation efforts to boost the export competitiveness.

Investment on Trade.- In a 'Cournot duopoly' model of international competition between a domestic and foreign firm, it is shown that when the foreign firm has incomplete information about the marginal cost of the domestic firm then the domestic government can use an export subsidy to signal the competitiveness of its firm. This 
signaling effect strengthens the usual profit-shifting argument for an export subsidy. The optimal export subsidy in the signaling equilibrium may be twice as large as the optimal profit-sharing export subsidy under complete information (Collie and Hviid, 1993). The subsidies on physical and financial resources including the fiscal incentives attract the foreign direct investments (FDI), which help in augmenting the export competitiveness of specialized goods and services in the region. The findings of one of the studies conducted on the impact of subsidies in FDI and export competitiveness reveal that linkages between the foreign and domestic sectors need to be improved if FDI is to be a vehicle for improving the competitiveness of domestic firms (Zheng et. al., 2004). The openness-growth connection is still an open question in the empirical literature. Although some studies have found that openness has a positive impact on economic performance, others have seriously questioned the significance of this result. One of the studies on Latin American trade issues emphasizes that openness involves more than just trade liberalization (Cuardos et.al., 2004). The increasing importance of international capital flows and especially foreign direct investment (FDI) seems to be another relevant component of outward oriented policies. Based on the quarterly data from the late seventies to 2000, the study investigates the effects of liberalization in Mexico, Brazil and Argentina by taking into account trade and FDI growth links. The results suggest that it is important to consider both exports and FDI to ascertain the benefits associated to the outward oriented strategies followed by these countries. New growth-trade theories have emphasized the contribution of international trade to economic growth through its effect on capital accumulation. A study with this focus tests the hypothesis that export oriented sectors attain higher rates of investment using panel data techniques and sectoral data from the Mexican manufacturing industry between 1970 and 1990 (Iscan, 1998). Despite the substantial variations in export shares across sectors and over time, the study can find no evidence supportive of the hypothesis that exports lead to capital accumulation. There is evidence that common determinants, such as the real exchange rate, may be behind the correlations between exports and investment rates found in cross-country studies. It has been observed in the previous studies that the economies that have advocated for open international trade gained higher rates of growth influenced by the higher rate of investment and factor productivity (Edwards, 1992, Harrison 1996).

A study focused on the relationship between entrepreneurship and successful export marketing performance revealed after testing the hypothesis that entrepreneurship is positively related to such performance (Haar and Buonafina, 2002). The research reveals that entrepreneurial behavior is positively correlated with export marketing behavior, suggesting government actions to boost competitiveness. Contemporary trends in the organization of multinational enterprises (MNEs), developments in regional economic integration, and evidence pertaining to the globalization of innovative activities are suggestive of the need to revisit the question of the contribution of overseas MNE affiliates to the technological capacity of developing countries. The study examining the contribution of European Union (EU) MNEs to the development of technological capacity in Mexico drawing upon small-scale survey and case study evidence reaffirms that the main contribution of EU MNEs is that of the long-standing one of MNEs in enhancing aspects of technological know-how in developing countries (Laura and Phelps, 2003). Yet the export orientation and status of 
EU MNE affiliates in Mexico appears to have been enhanced with regional economic integration and the anecdotal evidence from company case studies hints at possibilities for the future generations of technological know-how.

The private investment in developing countries is stimulated by real GDP growth, increases in government investment, improvements in financial intermediation, reductions in credit to the government, and declines in world interest rates. An interesting result of an empirical study relates to the important role played by educational development in stimulating private investment (Ghura and Goodwin, 2000). Nevertheless, statistically significant adverse effects of external debt on private investment found by other studies could not be confirmed by this study. In addition, the results for the full sample of countries are by no means common across the regions. While real GDP growth stimulated private investment in Asia and Latin America, its effect was not significant in Sub-Saharan Africa (SSA). Also, while government investment stimulated private investment in SSA, it had the opposite effect in Asia and Latin America. In addition, private investment was stimulated by increases in private sector credit in Asia and SSA, but not in Latin America. Also, increases in credit to the government had significant adverse effects on private investment in SSA and Latin America. The political economic consensus in Latin America has played significant role in crafting the trade and economy of the region. The splintering of the MERCOSUR following the Brazilian devaluation in early 1999 has given way to an important re-crafting of the regional vision and a significant expansion of the scope of the regional project. These trends can best be understood as coalescing into a new (and nascent) form of regionalist governance in the countries of the region, in which the MERCOSUR is reconfigured as a vehicle for a new set of developmentalist and strategic objectives (Phillips, 2001). This emerging form of regionalist governance is both causative and indicative of a new political economy both of the sub-region and of the wider region of the Americas, and reflective of the crystallization of a new political economy of development.

Theoretical Motivation.- The endogenous growth theory claims that physical capital growth alone cannot explain per capita output growth and that the neoclassical model fails to capture a number of crucial variables that explain economic growth. Their main contributions consist of including not only human capital (Romer, 1986, 1990, 1994; Barro, 1991; Lucas, 1988), but also international trade in goods (Eaton and Kortum, 1995, 1996; Rivera Batiz and Romer, 1991a, 1991b; Pissarides, 1997; Grossman and Helpman, 1991). By incorporating technological change, these models consider the diffusion of technology between countries, and the ability of developing countries to adopt and implement foreign technology. The decomposition of output growth demonstrates that factor growth generally proves to be more important than either the improved quality of factors or total factor productivity growth in explaining output growth. The quality of capital positively and significantly affects output growth in all groups. The quality of labor has a negative and notable effect on the overall economic growth in Latin America. The economic growth thus, associates with the declining quality deployment factors and vice versa. A growth accounting method for productivity and competitiveness has been determined using an integrated production function. The justification to choose this approach may be explained by the fact that 
during low growth period contributed by the firms in economic recession, the countries might have been forced to operate on the suboptimal manner with low levels of capacity utilization and this situation can be analyzed accurately. The construct of the model is explained below:

Total Factor Productivit.- The Cobb-Douglas function determines the relative influences of the factors of production. This model has been further interpreted in reference to the impact of factor dynamics resulted out of the structural reforms measures in LAC region, in terms of change in technology, investment, productivity and international trade. These factors, when considered with specific industrial sectors say, manufacturing industry determining the productivity in terms of income will generate competition index that would reveal the industry competitiveness, upon pooling. The model may be described as:

$$
\mathrm{Y}_{t}=\hat{\mathrm{Z}}_{t}\left[\mathrm{~K}_{t}^{\alpha} L_{t}^{(1-\alpha)}\right] \hat{Q}_{t}^{\infty}\left[I_{t}^{\beta} R_{t}^{1+\beta}\right]
$$

where, $\mathrm{Y}$ is the generated income out of factor productivity (pooled), $\hat{Z}$ is an index of TFP, $K$ and $L$ are the indicators of capital and labor availability and $Q^{\infty}$ is the projected output as a function of innovation $(I)$ and change in technology $(R)$. Dividing both sides by the intensity of change in factor "Yield" (y), taking Logs and first differentiating the rates of change per LAC countries, resulting into TFP $(\hat{Q})$ the equation may be constructed as:

$$
\ln \left[\frac{y_{t}}{y_{t-1}}\right]=\ln \left[\frac{\hat{\mathrm{Z}}_{t}}{\hat{\mathrm{Z}}_{t-1}}\right]+\alpha \ln \left[\frac{K_{t}}{K_{t-1}}\right]
$$

Trade Competitivenes.- It is assumed that the rate of growth of TFP can be expressed as a constant $(\lambda)$ with a random error (e). In the process of estimating the change in TFP that is reflected in the competitiveness in the international trade in LAC region, it is also assumed that $(\lambda)$ suffers a break during the structural reforms and the process of economic integration. The trade competitiveness in the study has been analyzed with reference to the variables openness, FDI, Portfolio, debt, Terms of Trade and export. The variability of $(\lambda)$ may be explained in reference to the equation (ii).

This leads to the following equation for estimation:

$$
\ln \left[\frac{y_{t}}{y_{t-1}}\right]=\lambda+\alpha \ln \left[\frac{K_{t}}{K_{t-1}}\right]+D_{x(r 1+r 2)}+\varepsilon_{t}
$$

Where $D_{x\left(r_{1}+r_{2}\right)}$ is the dummy variable activated in the years of structural reforms and economic integration. This variable has been calculated for recession period of reforms $D_{x r_{1}}$ and during reforms when the productivity contribution went negative $D_{x r_{2}}$. In all the equations, the demand function is assumed to have constant elasticities. The equation may be constructed as : 


$$
\ln x_{t}=\hat{p} \ln (r p)_{t}+\hat{y} \ln (m)_{t}+\varepsilon_{t}
$$

Where $x$ denotes the exports from LAC region during the reforms period, $r p$ is relative prices, $m$ is foreign real expenditure on manufactured good, $\hat{p}$ is price elasticity, $\hat{y}$ is income elasticity and e is the error term in the referred period.

Interplay of Trade Bloc.- It has been established through previous research studies (Riezman, 1999; Iscan, 1998; Phillips, 2001) that trade agreements play significant role in developing a favorable environment for trade and economy among the participating countries. In the model it is assumed that there are ' $\mathrm{N}$ ' trading blocs, where in the countries freely trade with each other ( $g$. NAFTA, CAFTA, MERCASUR). They could be a part of Free Trade Agreement (FTA), Customs Union (CU) or a simple N trading bloc condition. Assuming that there exist $\mathrm{N}$ Trading blocs in the LAC region and each bloc is endowed with a fixed amount of each commodity.

Let $B_{j}^{i}$ be the trading bloc $i$ in the region with an endowment of the commodity $j$, chosen for transaction under the bi-lateral trade agreement. ${ }^{1}$ The Cobb-Douglas performances exist in each trading blocs and the utility function, which can be derived out of the preferential trade agreements between the countries of trading bloc, may be described as

$$
U^{i}=\sum_{j=1}^{M} \alpha_{j}^{i} \ln \hat{A}_{j}^{i}
$$

Where $U^{i}$ is the utility of the trading bloc $i, \alpha_{j}^{i}$ is the weight that trading bloc i put on the commodity $j, \hat{A}_{j}^{i}$ is the aggregate consumption of $\mathrm{j}$ commodity in trading bloc $\mathrm{i}$ and $\mathrm{M}$ denotes different commodities that have the trade potential in the trading bloc. The volume of trade $V_{j}^{i}$ is described as $V_{j}^{i}=\hat{A}_{j}^{i}-B_{j}^{i}$, of which the positive values indicate imports from the point of view of trade competitiveness whereas the negative values represent exports in the trading bloc. The trading blocs impose a fixed value tariff $t$ which may be defined as advalorem duty charged in each trading bloc $i$ on import of $j$ commodity $\left(t_{j}^{i}\right)$. Under such circumstances, the prevailing international price for $j$ commodity may be described as $P_{r j}$. Accordingly the domestic price for the $j$ commodity in trading bloc $i$ would be $P_{r j}=\left(1+t_{j}^{i}\right) P_{r j}$. Hence the equation may be derived as below:

$$
\sum_{j=1}^{M} P_{r j}\left(1+t_{j}^{i}\right) \hat{A}_{j}^{i}=Y_{j \ldots n}^{i}=\sum_{j=1}^{M}\left(1+t_{j}^{i}\right) B_{j}^{i}+\left[\left(P_{r j}\right)\left(t_{j}^{i}\right)\left(V_{j}^{i}\right)\right]
$$

\footnotetext{
${ }^{1}$ If $B_{j}^{i}=0.4$ it means trading bloc $i$ is endowed with $40 \%$ of the regions endowment of commodity $j$.
} 
Where in $Y_{j}^{i}$ is the revenue granted in the trading bloc $i$ for the commodity $j$ up to ' $n$ ' potential commodities to be brought under trading. The equilibrium of the trade blocs within the given trade conditions, may be derived through the equations (v) and (vi):

$$
\sum_{j=1}^{M} P_{r j} \hat{A}_{j}^{i}=\sum_{j=1}^{M} P_{r j} \hat{B}_{j}^{i}=1
$$

And, towards the demand and supply, the equilibrium among the trading blocs may be achieved as described in the following equation.

$$
\sum_{i=1}^{N} \hat{A}_{j}^{i}=\sum_{i=1}^{N} \hat{B}_{j}^{i}=1
$$

At the equilibrium, the trade blocs would have aggregate expenditure equal to aggregate revenue, which may also be desired as endowment vector. Endowment may be explained as the sum of values of unilateral trade and consumption.

The measure of the economic welfare in reference to trade agreement has been computed using calibrated fraction $d$ which expresses the relationship between the fiscal allocation including taxes and gross revenue and trade equilibrium among the countries under study. Such equilibrium relationship is largely affected by the tariff regions of the participating countries. The welfare cost is derived using the following equation:-

$$
B^{t}\left(x_{1}, x_{2}, x_{3}\right)=B^{f t}\left[(1-\delta) x_{1},(1-\delta) x_{2},(1-\delta) x_{3}\right]
$$

Where $\mathrm{B}^{\mathrm{t}}$ denotes the benefits derived under an equilibrium with positive tariffs and $\mathrm{B}^{\mathrm{ft}}$ represents benefits derived in the given trade equilibrium emerged out of free trade agreements, common market structure or bilateral trade agreements.

Research Design. - The objective of this paper is to measure the extent of growth in the countries of LAC region as an outcome of economic growth and to assess the competitiveness emerged thereof. The study is limited to 11 countries of Latin American region. The principal data sets have been used from the published resources of Economic Commission on Latin America and Caribbean (ECLAC), World Development Reports and World Economic Outlook of respective years. The GDP measures constructed by the Nehru and Dareshwar (1993) have been referred in the study to derive calculations for the selected variables. The data has been analyzed using the dummy variables referring to the period of structural reforms in the region. A similar procedure has been applied by Lefort and Solimano (1994) to measure the economic growth during the recessional period. Similarly, Griliches and Lichetenberg (1984) made an assumption in a study measuring the long-run effects of technology transfer indicators on TFP growth. The principal variables used in the analysis are defined as below:

Gross national product $(V)$. Imports of goods and services $(M)$ Consumption of goods and services $(C)$. Savings $(S)$

Exports of goods and services $(E)$. Capital inflow $[F \equiv(M-E)]$

Gross domestic investment $(I)$. Reserves of foreign assets $(R)$

Growth rate of GNP $(r)$ 
In the analysis imports and exports are measured as net flows of returns on investments. The study postulates that a constant capitaloutput ratio $\left(k^{\prime}\right)$ for directly productive net investment and a constant share $(z)$ of current gross income, oriented to replacement and social overhead investment. Hence, gross investment in a given period may be represented by the equation:

$$
I_{t}=k^{\prime} \Delta V+z V_{t}
$$

Where, $\Delta V=V_{t+1}-V_{t}$. Since the traditional incremental capitaloutput ratio $k_{t}$ is defined as $I_{t} / \Delta V_{t}$ and since the growth rate of the following year $r_{t+1}$ is represented as $\Delta V_{t} / V_{t}$, dividing equation (x) by $\Delta V_{t}$ yields an equation for $k_{t}$ as a decreasing function of $r_{t+1}$ :

$$
k_{t}=k^{\prime}+\left(\frac{z}{r_{t+1}}\right)
$$

In the above equation $\left(k^{\prime}\right)$ is the marginal capitaloutput ratio that is relevant to increase in the level of investment in a given period. The required imports of a country in a given time may be expressed as:

$$
M_{t}=(M)_{t-1}+\mu \Delta V+\chi \Delta C+\phi \Delta(E / V)+\pi \Delta(R / V)
$$

Where, $\Delta$ refers to changes between the previous and the current period. In the above equation $\mu, \chi, \phi, \omega$ and $\pi$ are the constants indicating propensity to import, additional consumption, additional basic investment, export shares and ratio of reserves respectively in reference to imports during the pre- and post-reforms periods in the selected countries. Either the pair of parameter $\chi$ and $\phi$ or the parameter $\mu$ is zero in any given application of the above equation.

\section{Results and Discussion}

Table 1 shows the rates of growth of real Gross Domestic Product in Latin American countries during the period 1950-2003.

Table 1: Growth of GDP in the Latin American Countries

(In percent)

\begin{tabular}{|l|c|c|c|c|c|c|}
\hline Countries/Period & $1951-60$ & $1961-70$ & $1971-80$ & $1981-1990$ & $1991-2000$ & 2003 \\
\hline Argentina & 2.9 & 4.4 & 2.8 & -0.6 & 4.6 & 8.6 \\
\hline Brazil & 6.8 & 6.1 & 8.7 & 1.7 & 2.6 & -0.4 \\
\hline Chile & 4.0 & 4.3 & 2.7 & 3.2 & 6.0 & 3.3 \\
\hline Colombia & 4.7 & 5.2 & 5.4 & 3.7 & 2.6 & 3.7 \\
\hline Costa Rica & 7.3 & 6.8 & 5.5 & 2.3 & 4.4 & 6.4 \\
\hline Ecuador & 5.0 & 4.8 & 9.0 & 1.8 & 1.8 & 2.5 \\
\hline Mexico & 6.1 & 7.0 & 6.7 & 1.9 & 3.3 & 1.2 \\
\hline Paraguay & 2.8 & 4.7 & 8.7 & 3.1 & 2.8 & 2.5 \\
\hline Peru & 5.5 & 5.1 & 3.9 & -0.8 & 4.7 & 4.1 \\
\hline Uruguay & 2.2 & 1.6 & 3.1 & 0.2 & 3.2 & 2.3 \\
\hline Venezuela & 7.6 & 6.0 & 1.9 & $-0,5$ & 2.1 & -9.3 \\
\hline
\end{tabular}

Source: Economic Commission for Latin America and Caribbean (ECLAC) 
The data presented in the Table 2 show that the growth rates vary from 2.8 for Argentina to 6.9 for Venezuela. However the study revealed that capital requirements were also highest for Argentina (14.3) followed by Columbia (10.5), Ecuador (7.4) and Mexico (5.7). The capital requirement for Venezuela has been found the slowest (0.5). The export growth rate for Peru has emerged as the highest (5.5) while it has been held back for Argentina (3.6). The export growth rate found for Mexico during the period of study was above average (4.9). Other studies have also arrived at similar results. Mexico, a prominent liberalizer, failed to attain stellar gross domestic product (GDP) growth in the 1990s, and since 2001 its GDP and exports have stagnated (Tornell, et.al, 2004). Brazil, Mexico and Uruguay experienced average rate of output growth to the extent of 4 percent as compared to the 2.8 percent of the pre-reforms period. The contribution of productivity as a fraction of GDP growth has a steep decline in Mexico and a slow rate of decline in Paraguay during the post-reforms period.

Table 2: Historical Parameters and Growth Rates in the Periods of Reforms and NoReforms of the Economy, 1950-2003

\begin{tabular}{|l|c|c|c|c|c|c|c|c|c|}
\hline Country & \multicolumn{5}{|c|}{ Imports } & Exports & \multicolumn{2}{c|}{$\begin{array}{c}\text { Capital } \\
\text { Requirement }\end{array}$} & $\begin{array}{c}\text { GNP } \\
\text { Growth }\end{array}$ \\
\hline Status & $\begin{array}{c}\Delta V \\
(\mu)\end{array}$ & $\begin{array}{c}\Delta C \\
(\chi)\end{array}$ & $\begin{array}{c}\Delta I \\
(\phi)\end{array}$ & $\begin{array}{c}\Delta E \\
V \\
(\omega)\end{array}$ & $\begin{array}{c}\Delta R \\
(\pi) \\
\left(\varepsilon^{\prime \prime}\right)\end{array}$ & $\begin{array}{c}\text { Intercept } \\
\left(k^{\prime}\right)\end{array}$ & $\left(r_{t+1}\right)$ & $(r)$ \\
\hline Argentina & 0.016 & 0.025 & 0.264 & 228 & 119 & 0.036 & 2.13 & 0.149 & 0.028 \\
\hline Brazil & 0.054 & 0.003 & 0.392 & 751 & 26040 & 0.047 & 2.19 & 0.055 & 0.059 \\
\hline Chile & 0.051 & 0.141 & 0.412 & 2299 & 4423 & 0.041 & 2.04 & 0.041 & 0.033 \\
\hline Colombia & 0.028 & 0.109 & 0.556 & 2196 & 1753 & 0.106 & 2.32 & 0.105 & 0.049 \\
\hline $\begin{array}{l}\text { Costa } \\
\text { Rica }\end{array}$ & 0.035 & 0.265 & 0.468 & 433 & 77 & 0.067 & 2.41 & 0.066 & 0.054 \\
\hline Ecuador & 0.036 & 0.054 & 0.763 & 489 & 337 & 0.074 & 2.00 & 0.072 & 0.039 \\
\hline Mexico & 0.310 & 0.097 & 0.145 & 3642 & 8144 & 0.049 & 2.05 & 0.055 & 0.061 \\
\hline Paraguay & 0.032 & 0.174 & 0.339 & 193 & 124 & 0.014 & 2.96 & 0.046 & 0.031 \\
\hline Peru & 0.045 & 0.162 & 0.597 & 260 & 265 & 0.051 & 2.29 & 0.067 & 0.042 \\
\hline Uruguay & 0.040 & 0.028 & 0.377 & 1103 & 542 & 0.016 & 2.58 & 0.047 & 0.054 \\
\hline Venezuela & 0.250 & 0.194 & 0.482 & 1875 & 986 & 0.025 & 3.24 & 0.005 & 0.069 \\
\hline
\end{tabular}

Source: Based on the data computation done by the author.

The relationship between domestic savings $(S)$ assumed to be the function of GNP $(V)$, the inflow of foreign capital $(F)$ and the share of exports in GNP $(E / V)$ have been tested by fitting the regression equation. The Table 3 reveals that the impact of additional foreign capital on savings was found to be negative for all the countries in the study except Venezuela but the impact of export share was positive. In the reference to the period of study, the inflow of foreign capital has increased for almost all countries covered in the study. The trend in export share rose during the postreforms period (1980-2000) in all the selected countries. However, these results are not conclusive that the trade competition has been the dominant factor for most of the 
Latin American countries towards augmenting their export share. The long-run effect of reforms would prevail if sustained during the process and may be influenced by the sum of the contemporaneous and the delayed impacts. If the latter is negative, some of the achievements of growth would be lost in the future. If positive, additional growth would occur effortlessly (Rajagopal, 2005).

Table 3: Regression results for factors of economic growth in Latin American countries (1950-2003)

\begin{tabular}{|c|c|c|c|c|c|c|c|c|c|c|}
\hline \multirow[t]{2}{*}{ Country } & \multirow[t]{2}{*}{ Intercept } & \multirow[t]{2}{*}{$\mathrm{V}^{\mathrm{a}}$} & \multirow[t]{2}{*}{$\mathrm{R}^{2}$} & \multirow[t]{2}{*}{ Intercept } & \multirow[t]{2}{*}{$\mathrm{V}^{\mathrm{a}}$} & \multirow{2}{*}{$(E / V)^{a}$} & \multirow[t]{2}{*}{$\mathrm{F}^{\mathrm{a}}$} & \multirow[t]{2}{*}{$\mathrm{R}^{2}$} & \multicolumn{2}{|c|}{$\begin{array}{c}\text { Correlation with } \\
\text { Time }(1980-2003)^{\mathrm{b}}\end{array}$} \\
\hline & & & & & & & & & $(E /)$ & $\mathrm{F}$ \\
\hline Argentina & -998.3 & $\begin{array}{l}-0.30 \\
(4.01)\end{array}$ & 0.52 & -674.1 & $\begin{array}{c}0.37 \\
(6.99)\end{array}$ & $\begin{array}{l}5655.2 \\
(2.02)\end{array}$ & $\begin{array}{l}-0.54 \\
(3.87)\end{array}$ & 0.72 & $\begin{array}{c}-0.04 \\
(-0.12)\end{array}$ & $\begin{array}{l}-0.09 \\
(0.37)\end{array}$ \\
\hline Brazil & 274.3 & $\begin{array}{l}-0.153 \\
(6.43)\end{array}$ & 0.29 & -203.0 & $\begin{array}{l}0.241 \\
(4.52)\end{array}$ & $\begin{array}{l}4721.6 \\
(1.63)\end{array}$ & $\begin{array}{l}0.644 \\
(1.99)\end{array}$ & 0.66 & $\begin{array}{c}0.58 \\
(-0.36)\end{array}$ & $\begin{array}{c}0.61 \\
(0.14)\end{array}$ \\
\hline Chile & 35.4 & $\begin{array}{l}0.241 \\
(3.72)\end{array}$ & 0.46 & -383.3 & $\begin{array}{l}0.143 \\
(3.58)\end{array}$ & $\begin{array}{l}2715.3 \\
(2.15)\end{array}$ & $\begin{array}{l}0.067 \\
(1.33)\end{array}$ & 0.48 & $\begin{array}{c}-0.37 \\
(-0.64)\end{array}$ & $\begin{array}{c}0.43 \\
(-0.27)\end{array}$ \\
\hline Colombia & 443.2 & $\begin{array}{l}0.094 \\
(3.15)\end{array}$ & 0.36 & -471.2 & $\begin{array}{l}0.127 \\
(3.96)\end{array}$ & $\begin{array}{l}2652.5 \\
(3.96)\end{array}$ & $\begin{array}{l}-0.36 \\
(1.84)\end{array}$ & 0.73 & $\begin{array}{c}-0.83 \\
(-0.97)\end{array}$ & $\begin{array}{c}0.11 \\
(-0.19)\end{array}$ \\
\hline $\begin{array}{c}\text { Costa } \\
\text { Rica }\end{array}$ & 72.3 & $\begin{array}{l}-0.024 \\
(1.16)\end{array}$ & 0.12 & 16.5 & $\begin{array}{l}0.052 \\
(1.23)\end{array}$ & $\begin{array}{l}902.4 \\
(1.44)\end{array}$ & $\begin{array}{l}-0.27 \\
(1.27)\end{array}$ & 0.25 & $\begin{array}{c}-0.14 \\
(-0-36)\end{array}$ & $\begin{array}{c}0.33 \\
(-0.45)\end{array}$ \\
\hline Ecuador & 11.9 & $\begin{array}{l}-0.163 \\
(9.63)\end{array}$ & 0.92 & -34.6 & $\begin{array}{l}0.172 \\
(8.77)\end{array}$ & $\begin{array}{l}-439.7 \\
(1.77)\end{array}$ & $\begin{array}{l}-0.145 \\
(2.65)\end{array}$ & 0.73 & $\begin{array}{c}-0.24 \\
(-0.56)\end{array}$ & $\begin{array}{l}-0.10 \\
(-0.38)\end{array}$ \\
\hline México & 164.6 & $\begin{array}{l}0.146 \\
(5.63)\end{array}$ & 0.66 & -936.3 & $\begin{array}{l}0.223 \\
(6.33)\end{array}$ & $\begin{array}{l}7633.7 \\
(2.07)\end{array}$ & $\begin{array}{l}-0.76 \\
(3.49)\end{array}$ & 0.92 & $\begin{array}{c}0.56 \\
(-0.34)\end{array}$ & $\begin{array}{c}0.55 \\
(-0.21)\end{array}$ \\
\hline Paraguay & 12.4 & $\begin{array}{l}-0.134 \\
(3.95)\end{array}$ & 0.48 & 18.6 & $\begin{array}{l}0.147 \\
(3.64)\end{array}$ & $\begin{array}{l}-554.7 \\
(2.57)\end{array}$ & $\begin{array}{l}0.042 \\
(2.66)\end{array}$ & 0.39 & $\begin{array}{c}-0.14 \\
(-0.58)\end{array}$ & $\begin{array}{c}0.42 \\
(0.14)\end{array}$ \\
\hline Peru & 5.9 & $\begin{array}{l}0.231 \\
(6.94)\end{array}$ & 0.76 & -46.3 & $\begin{array}{l}0.262 \\
(7.54)\end{array}$ & $\begin{array}{l}1422.9 \\
(1.90)\end{array}$ & $\begin{array}{l}-0.051 \\
(3.67)\end{array}$ & 0.63 & $\begin{array}{c}-0.39 \\
(-0.44)\end{array}$ & $\begin{array}{c}-0.49 \\
(-0.59)\end{array}$ \\
\hline Uruguay & 34.8 & $\begin{array}{l}-0.124 \\
(2.34)\end{array}$ & 0.45 & -11.7 & $\begin{array}{l}0.155 \\
(3.22)\end{array}$ & $\begin{array}{l}-342.7 \\
(3.92)\end{array}$ & $\begin{array}{l}-0.345 \\
(2.41)\end{array}$ & 0.42 & $\begin{array}{c}-0.63 \\
(-0.74)\end{array}$ & $\begin{array}{c}0.19 \\
(-0.27)\end{array}$ \\
\hline Venezuela & 692.4 & $\begin{array}{l}0.091 \\
(3.26)\end{array}$ & 0.37 & 342.4 & $\begin{array}{l}0.082 \\
(3.74)\end{array}$ & $\begin{array}{l}126.0 \\
(1.22)\end{array}$ & $\begin{array}{l}0.162 \\
(1.14)\end{array}$ & 0.54 & $\begin{array}{c}0.22 \\
(-0.32)\end{array}$ & $\begin{array}{c}0.29 \\
(0.13)\end{array}$ \\
\hline
\end{tabular}

Source: Based on the data computation done by the author.

${ }^{\mathrm{a}}$ Figures in parentheses are standard deviations

${ }^{\mathrm{b}}$ Figures in parentheses refer to the period 1950-1979

The Central American countries have shown good growth results during the reforms period, though Chile has shown extraordinary growth during the referred period. Mexico, Argentina and Brazil also show an increasing trend in the economic growth which is largely influenced by the increasing exports share during the reforms period. The countries which experienced decline in the export share include Venezuela, Columbia and Paraguay. The model used for the projections of export growth (2015) has been conceived as largely exogenous. An export sector responsive to the trade situation of the country is assumed for "high performance". The exogenous growth rate of exports has been derived through the following equation:

$$
E_{t}=E_{0}\left(1+\varepsilon^{\prime \prime}\right)^{t}
$$


Where in, $\left(\varepsilon^{\prime \prime}\right)$ represents exogenous growth rate of exports $(E), E_{t}$ denotes the exports of goods and services in the reforms period and $E_{0}$ exhibits the historical performance of the exports of the countries in the region. The results exhibited in Table 4 reveal that all the countries selected in the study show faster growth in exports though the actual growth may be reflected by the trade policies of theses countries implemented through the type of agreements e.g. free trade agreement, common market or bilateral trade. As measured by the adjusted $R^{2}$, the fit of this dynamic specification is slightly better than that of its static counterpart. Moreover, in the dynamic specification, education is statistically significant. The evidence thus suggests the presence of a minor partial offset to the beneficial growth effect of stabilization during the post-reforms years. Assuming low variation in the regional economic growth and taking the estimates at their face values, the income effect is immediate, the short term effect from relative prices is lagged, and the estimated short run price elasticity (-)0.3 is lower in absolute value than the long run elasticity (-)1.3. These results are common in the analysis of time-series data of foreign trade (Rajagopal, 2005). While using regression results to project savings behavior, it has been assumed that the observed coefficients on GNP and export share describe the coefficient on foreign capital. The equation for potential savings $(S)$ is hence derived as:

$$
(S)_{t}=(S)_{t-1}+\alpha \Delta V+\gamma \Delta(E / V)
$$

Where, $\Delta$ refers to the change between the pre-reforms period $(t-1)$ and the reforms period $(t)$. In the equation $\alpha$ represents propensity to save from additional GNP and $\gamma$ denotes the effect of changes in export share on savings.

Table 4: Economic Competitiveness in the Latin American Countries (1980-2003)

\begin{tabular}{|c|c|c|c|c|}
\hline \multirow[t]{2}{*}{ Country } & \multicolumn{2}{|c|}{$\begin{array}{l}\text { Savings } \\
\end{array}$} & \multirow{2}{*}{$\begin{array}{l}\text { Export Growth } \\
\left(\varepsilon^{\prime \prime}\right)\end{array}$} & \multirow{2}{*}{$\begin{array}{c}\text { GNP } \\
\text { Growth } \\
r\end{array}$} \\
\hline & $\begin{array}{c}\alpha \\
(\delta s / \delta V)\end{array}$ & $\begin{array}{c}\gamma \\
(\delta s / \delta E / V)\end{array}$ & & \\
\hline Argentina & 0.354 & 6624 & 0.036 & 0.054 \\
\hline Brazil & 0.295 & 6541 & 0.047 & 0.067 \\
\hline Chile & 0.247 & 1120 & 0.039 & 0.058 \\
\hline Colombia & 0.286 & 2610 & 0.106 & 0.064 \\
\hline Costa Rica & 0.255 & 966 & 0.057 & 0.066 \\
\hline Ecuador & 0.266 & 139 & 0.074 & 0.057 \\
\hline México & 0.284 & 9442 & 0.049 & 0.061 \\
\hline Paraguay & 0.245 & 254 & 0.009 & 0.054 \\
\hline Peru & 0.237 & 1233 & 0.041 & 0.066 \\
\hline Uruguay & 0.311 & 536 & 0.019 & 0.061 \\
\hline Venezuela & 0.310 & 995 & 0.025 & 0.077 \\
\hline
\end{tabular}

Source: Based on the data computation done by the author 
Since the welfare measure leading to the economic benefit emerging out of foreign trade agreements has been computed in terms of tariff region (taxes) and revenue, it provides an estimate of percentage change in the revenue as an indicator of economic welfare through trade agreements. The economic welfare indicators associated with Nash equilibrium is discussed in the Table 5.

Table 5: Welfare Equilibrium in Trading Blocs in Latin America

\begin{tabular}{|c|c|c|c|c|}
\hline Trade Blocs & NE & FTA & CM & BT \\
\hline 1 & 2.079 & 1.235 & 0.493 & 0.079 \\
\hline 2 & 1.532 & 0.928 & 1.163 & 1.212 \\
\hline 3 & 1.670 & 0.946 & 1.325 & 1.495 \\
\hline LAC Region & 1.752 & 0.986 & 1.012 & 0.929 \\
\hline
\end{tabular}

Trade Blocs 1 = NAFTA (FTA- Free Trade Agreement). 2 = Common Market (CM) MERCOSUR. 3 = Bilateral Trade (BT) between two countries on mutually convenient agreement. $\mathrm{NE}=$ Nash Equilibrium

The results reveal that NAFTA (Trading Bloc 1) has gained over the other two trading blocs in terms of revenue though the trading costs were higher. Each trading bloc approximately gains $1.5 \%$ higher in the LAC region, by changing optimal tariff. The trading bloc 2 has gained marginally lesser than the trading bloc 3 which is formed out of bilateral trade agreements. This leads to smaller tariffs and lower economic welfare gains. The analysis of economic welfare gains through Nash equilibrium allows critical examination of the optimal policy in an economy that evolves around take-off state, which is not necessarily efficient.

\section{Conclusion}

During early1980s, the private sector in Latin America faced a very uncomfortable economic environment. Inflation was high; there were sharp currency fluctuations which, in turn, led to acute price volatility; investment was low and import substitution prompted low production, state interventionism, large foreign debt and severe balance of payment deficits. The whole region suffered a strong macroeconomic state of imbalance, which required strong remedies. The subsequent stabilization and structural adjustment programs aimed to reduce fiscal deficits, open up economies, privatize state enterprises, reduce foreign debt, introduce flexible exchange rates and modernize the financial system. The opening up of markets can play an important role in weakening vested interests and reducing economic rents associated with long standing economic and institutional arrangements. Trade can thus spur improvement in domestic institutions that otherwise would not have been possible. In addition, international agreements can be an important external anchor and catalyst for institutional change by breaking through domestic impediments to reforms.

The high performance in savings, exports share and reserves of foreign assets would permit accelerated growth to occur with increase in the cumulative capital inflow. Hence, the Latin American countries may develop policies to identify resources, which would promote the domestic savings and growth of GNP. The increase in inflow of capital would help stimulating improved domestic development performance. The 
long-run accelerated growth at the cost of external resources may be less than the prereforms experience of the countries in resources management. The discussion in the paper reveals that growth rates tend to fall only temporarily following a balance-ofpayments crisis and then rebound to the pre-crisis levels in some of the Latin American countries. However, a balance-of-payments issue is often associated with a decline of growth rates and may run into the export crisis in the future. The results of the study determine that international liquidity, financial soundness, real exchange rate depreciation and monetary policy play a critical role in reducing output losses and increasing the economic welfare gains. It has been discussed in the paper that while applying the Nash equilibrium, gains from trade liberalization rise through the various types of trade agreements, however, that stem from the impact of foreign economic activity on the domestic marginal cost of production. The trade competitiveness reflects significantly in reference to the welfare losses and gains. The variables that determine the efficacy of the trading blocs include exchange rates, foreign direct investments, total factor productivity and growth in exports. The interest rates in response to domestic inflation need to be adjusted to foreign inflation within the trading blocs in order to optimize the economic welfare gains.

\section{References}

Bair, J. (2002), Beyond the Maquila Model - NAFTA and the Mexican Apparel Industry, Industry and Innovation, Vol.9-3,pp 203-205

Barro, R.J (1991), Economic Growth in a Cross Section of Countries, Quarterly Journal of Economics, 106, pp 407-443

Bhagwati, J. and A. Panagariya, 1996, Preferential trading areas and multilateralism: strangers, friends or foes?, in Free Trade Areas or Free Trade? The Economics of Preferential Trading Agreements in J. Bhagwati and A. Panagariya (eds.), AEI Press

Catao, L. and Falcetti, E. (2002), Determinants of Argentina's External Trade, Journal of Applied Economics, Vol. 5, No. 1, pp 19-57

Collie, D. and Hviid, M.(1993), Export Subsidies as Signals of Competitiveness, Scandinavian Journal of Economics, Vol.95, No.3, pp 327-339

Cuardos An, Orts Vicente and Algnacil Maite (2004), Openness in Growth: Reexamining Foreign Direct Investment, Trade and Output Linkages in Latin America, The Journal of Development Studies, Vol.40-4, pp 167-192

Djistra A G (2000), Trade Liberalization and Industrial Development in Latin America, World Development, Vol.28, No.9, pp 1567-1582

Eaton Jonathan and Samuel Kortum (1995), Engines of Growth - Domestic and Foreign Sources of Innovation, National Bureau of Economic Research Inc., NBER Working Paper 5207

Eaton, J. and Samuel, K. (1996), Measuring Technology Diffusion and the International Sources of Growth, Eastern Economic Journal, 22 (4), pp 401-410

Edwards S (1992), Trade orientation, Distortions and Growth in Developing Countries, Journal of Development Economics, 39, pp 31-57

Frankel, J. A and Romer, D. (1999), Does Trade Cause Growth? American Economic Review, Vol. 89, No. 3, pp 379-399

Ghura, D. and Goodwin, B. (2000), Determinants of Private Investment - A Cross-regional Empirical Investigation, Applied Economics, Vol. 32, No. 14. pp. 1819-1829.

Glick, R. and Moreno, R. (1999), Money and Credit, Competitiveness and Currency Crisis in Asia and Latin America, Federal Reserve Bank of San Francisco, Pacific Basin Working Paper series No. 99-01, pp 7-38 
Griliches, Z. and F. Lichtenberg (1984): $R \& D$ and Productivity Growth at Industry Level: Is There Still a Relationship?, in Griliches Z. (ed.), R\&D, Patents and Productivity, Chicago: University of Chicago Press, pp465-501

Grossman Gene M and Elhanan Helpman (1991), Innovation and Growth in the Global Economy, MIT Press, Cambridge

Haar, J. and Buonafina, M. (2002), Entrepreneurial Exporters: The Canadian Experience, The International Trade Journal, Vol. 16, No.1. pp 31-71

Harrison A (1996): Openness and Growth - A Time-series, Cross-country Analysis for Developing Countries, Journal of Development Economics, 48 (2), March, pp 419-447

Paunovic, I. (2000), Growth and Reforms in Latin America and the Caribbean in the 1990s, United Nations Economic Commission for Latin America and the Caribbean (ECLAC), Working Paper, Economic Division.

Iscan, T. (1998), Exports and Capital Accumulation - Some Empirical Evidence from Mexican Manufacturing Industry, Applied Economic Letters, Vol.5, No. 6, pp 355-360

Vera, J.(2001), From Globalization to Upgrading Value in the Productive Chain in Specialized Agglomerations: Is Local Space Still Important? - Evidence from Mexico, ERSA Conference Paper, European Regional Science Association, Vienna, August.

Joseph, J. and Kamas, L. (2003), Real and Nominal Determinants of Real Exchange Rates in Latin America - Short-run Dynamics and Long-run Equilibrium, The Journal of Development Studies, Vol.39, No. 6, pp 155-182

Kaltenthaler, K. and Mora, F. O (2002), Explaining Latin American Economic Integration The Case of MERCOSUR, Review of International Political Economy, Vol. 9, No.1, pp 72-97

Kamin, S.(1998), A Multi Country Comparison of the Linkages between Inflation and Exchange Rate Competitiveness, Federal Reserve bank of US, International Finance Discussion Paper No. 603

Krueger, A O (1995), Free Trade Agreements versus Customs Unions, NBER WP\#5084

Krugman, P. (1994), Competitiveness - A Dangerous Obsession, Foreign Affairs, Vol. 73. No.2, pp 28-44

Martinez- Solano, L. and Phelps NA (2003), The Technological Activities of EU MNEs in Mexico, International Planning Studies, Vol. 8, No. 1. pp. 53-75.

Lefort F and Solimano A (1994): Economic Growth after Market Based Reforms in Latin America : The Case of Chile and Mexico, Working Paper, Macro Economic and Growth Division, World Bank, Washington DC

Leon, I. de (2001), A Market Process Analysis of Competition Policy in Latin America, Catholic University of Adres Bellow (UCAB), Venezuela, Working Paper

Loser Claudio M and Guerguil Martin (1999), Trade and Trade Reform in Latin America and the Caribbean in the 1990's, Journal of Applied Economics, Vol. 2, No. 1, pp 61-96

Lucas, R. E (1998), On the Mechanics of Economic Development, Journal of Monetary Economics, 22, pp 3-42

Marshall, D. D (1998), NATFA/FTAA and the New Articulations in Americas - Seizing Structural Opportunities, Third World Quarterly, Vol. 19, No. 4, pp 673-700

Michaely, M. (1999), Trade Preferential Agreements in Latin America: An Ex-Ante Assessment, The World Bank Policy Research Working Paper Series, No. 1583

Mody, A. and Yilmaz K. (2002), Imported Machinery for Export Competitiveness, World Bank Economic Review, Vol. 16, June, pp 23-48

Mortimore M (1998), Getting a Lift - Modernizing Industry by way of Latin American Integration Schemes, Transnational Corporations, Vol.7, No.2, pp 97-136

Nehru V and Dhareshwar A (1993): A New Database on Physical Capital Stocks - Sources Methodology and Results, Revista de Analysis Economico, 8, June, pp 37-59 
Nordstrom, H., (1995), Customs Unions, Regional Trading Blocs and Welfare, in R. Baldwin, P. Haaparanta, and J. Kiander (eds.), Expanding Membership of the European Union,

Cambridge University Press, pp 54-78.

Paus Eva, Reinhardt Nola and Robinson Michael (2003), Trade Liberalization and Productivity Growth in Latin American Manufacturing, The Journal of Policy Reforms, Vol. 6, No.1, pp 1-15

Perroni, C. and Whalley, J (1996), How Severe is the Global Retaliation Risk under Increasing Regionalism, American Economic Review, Vol. 86, No. 2, pp 57-61

Phillips, N. (2001), Regionalist Governance in the New Political Economy of Development: Re-launching the "Mercosur", Third World Quarterly, Vol. 22, No. 4, pp. 565-583.

Pissarides, Ch.A (1997), Learning by Trading and the Returns to Human Capital in Developing Countries, The World Bank Economic Review, Vol.11, No. 1, pp 19-32

Pritchett, L (1996): Measuring Outward Orientation in LDCs - Cant it be Done? Journal of Development Economics, Vol. 49, No.2, pp 307-335

Rajagopal (2004), Economic Integration and Trade Competitiveness in Latin America and Caribbean, ITESM, Working Paper, 7/2004 pp 1-28

Rajagopal (2005), Institutional Reforms and Trade Competitiveness in Latin America, Applied Econometrics and International Development, Vol. 5, No.1 pp 45-64

Rajapatirana, S. (1994), The Interface of Trade, Investment and Competition Policies : Issues and Challenges for Latin America, World Bank, Latin America and Caribbean Department, Report \# 009

Riezman, R.(1999), Can Bilateral Trade Agreements Help Induce Free Trade?, Centre for the Strudy of Globalization and Regionalization, University of Warwick, CSGR Working Paper \# 44/99, pp 1-2,3

Rivera-Batiz, L. and Romer, P (1991a), International Trade with Endogenous Technological Change, European Economic Review, Vol. 35, pp 971-1004

Rivera-Batiz, L. and Romer, P (1991b), Economic Integration and Endogenous Growth, Quarterly Journal of Economics, Vol.106, No. 2, May, pp 531-555

Romer, P. M (1986), Increasing Returns and Long-rum Growth, Journal of Political Economy, Vol. 94, October, pp 1002-1036

Romer, P. M (1990), Endogenous Technological Change, Journal of Political Economy, Vol. 98, pp 71-102

Romer, P. M (1994), The Origins of Endogenous Growth, Journal of Economic Perspectives, Vol. 8, Winter, pp 2-22

Thacker Storm C (2000), Private Sector Trade Politics in Mexico, Business and Politics, Vol. 2, No.2, pp 161-187

Tornell, A., Westermann, F. and Martinez, L. (2004), NAFTA and Mexico's Economic Performance, Center for Economic Studies and Ifo Institute for Economic Research, Working Paper Series No. 1155, March.

Vogel, D. (1997), Trading Up and Governing Across - Transnational Governance and Environment Protection, Journal of European Public Policy, Vol.4, No.4, pp 556-571

Zheng, P., Siler, P. and Giorgioni, G. (2004), FDI and the Export Performance of Chinese Indigenous Firms: A Regonal Approach, Journal of Chinese Economic and Business Studies, Vol. 2, No.1, pp 55-71

Journal published by the Euro-American Association of Economic Development. http://www.usc.es/economet/eaa.htm 